\title{
Status, habitat and conservation of the St Helena Wirebird Charadrius sanctaehelenae
}

\author{
M. NEIL McCULLOCH
}

\begin{abstract}
Summary
The St Helena Wirebird, a sand plover, is the last surviving endemic bird on the South Atlantic island of St Helena. Census work carried out during 1988-1989 located a maximum of 495 individuals. This is thought to be close to the true size of the population and is more than $50 \%$ higher than the most recent previous estimate. Population trends remain unknown, however. Breeding success appears to be low. A maximum survival rate from egg to independence of $19 \%$ was estimated. Predation and disturbance of Wirebirds is discussed. Wirebirds occur in grassland and semi-desert. Highest densities are found in relatively dry, flat pastures. Wetter upland pastures hold few Wirebirds, possibly because of more difficult feeding conditions encountered in taller, denser vegetation on steep slopes. Wirebirds prey on a wide range of invertebrates but beetles and caterpillars appear to predominate in the diet. Possible future threats, principally changes in land-use, were assessed and a management strategy for the species is outlined.
\end{abstract}

\section{Introduction}

\section{St Helena}

The South Atlantic island of St Helena $\left(15^{\circ} 56^{\prime} \mathrm{S} 5^{\circ} 42^{\prime} \mathrm{W}\right)$ is one of the most isolated land-masses in the world. It lies some $1,900 \mathrm{~km}$ west of Africa and $3,300 \mathrm{~km}$ east of South America. The nearest land is Ascension Island $1,100 \mathrm{~km}$ to the north-west. Although St Helena covers an area of only $122 \mathrm{~km}^{2}$ and has maximum dimensions of $16 \mathrm{~km}$ by $10 \mathrm{~km}$ its extreme isolation has been a catalyst in the evolution of a surprising number of endemic animals and plants (Brown 1982, Cronk 1987).

It is known from sub-fossil remains that at least six endemic terrestrial bird species have occurred on the island (Ashmole 1963, Olson 1975). Five of these appear to have persisted into historical times (Olson 1975). It seems likely that other species, probably including small passerines, also existed on St Helena but evidence has yet to be found.

St Helena was discovered by the Portuguese navigator João da Nova Castella in 1502. The island's natural vegetation has been almost totally destroyed subsequently, resulting in extensive erosion and land degradation (Cronk 1983, 1986a,b, 1989). The consequences of this environmental disruption and the introduction of predators such as cats, dogs, rats and pigs included the extinction of all the endemic landbirds with the exception of the St Helena Plover, known locally as the Wirebird Charadrius sanctaehelenae, and a severe reduction in 
the numbers and diversity of breeding seabirds. The terrestrial avifauna of St Helena today consists of eleven breeding species. All but two of these have been deliberately introduced to the island by man.

\section{The Wirebird: general considerations and early history}

The Wirebird is closely related to Kittlitz's Sand-plover C. pecuarius of Africa, with which it undoubtedly shares common ancestry, and has often been treated as conspecific (e.g. Sclater 1924, Bock 1958). Although the Wirebird closely resembles $C$. pecuarius it is substantially larger and differs markedly in its physical proportions: for example, its tarsus length is around $40 \%$ longer than that of C. pecuarius though sternum length is only 10\% greater (Olson 1975). The Wirebird's bill is also disproportionately longer.

The Wirebird's wing is more rounded and its pectoral muscles are relatively smaller than those of $C$. pecuarius. More extreme examples of such trends are evident in other endemic landbirds, most of which appear to have been flightless or to have had considerably reduced powers of flight (Olson 1975). The Wirebird's retention of efficient flight has undoubtedly assisted its survival in the face of introduced predators.

It is not known when the Wirebird's ancestors first reached St Helena but bones found by Olson (1975) appear to be at least 1,500 years old and some may date from the early Pleistocene. The birds from which these bones came were all larger than typical $C$. pecuarius, so considerable evolutionary divergence may have taken place fairly rapidly. Colonization of St Helena by African birds during the lower Pleistocene is likely to have been favoured by the greater strength of the South-East Trade Winds at this time (Baker 1970).

Most of the earliest reports describe St Helena as being heavily wooded but it seems probable that substantial areas of the windward side of the island consisted of scrub (Cronk 1989). The more open parts of this were probably the original habitat of the ancestral Wirebirds. As an open-country species, the Wirebird was probably the only endemic bird to benefit from the widespread deforestation that occurred after human colonization of the island.

The actual effects of these environmental changes on the Wirebird population are unknown, as the species has been little studied since the English traveller Peter Mundy noted in 1634 that, on St Helena, there was "a small land Foule and butt only that kind here to be seen" (Temple 1919: 413). In 1656 Mundy returned to the island and recorded the first description of the Wirebird, stating that it was "somewhatt like a larke in collour, shape, flightt and note. It would run like a lapwing" (Temple and Anstey 1936: 79). By this time major environmental changes had already occurred. Pigs and goats were present by 1536 (Markham 1911), the latter having possibly been introduced as early as 1513. By 1588 Captain Thomas Cavendish was able to see herds of hundreds of goats during his visit to St Helena (Gosse 1938: 18). The presence of feral cats and dogs was noted by Mundy in 1634 (Temple 1914: 330). Black rats Rattus rattus probably first came ashore very soon after the discovery of the island and were certainly a serious pest by 1666 (Gosse 1938: 54). The brown rat $R$. norvegicus appears to have become established during the eighteenth century (Atkinson 1985). Perma- 
nent human settlement dates from 1659 when the island passed into the ownership of the English East India Company.

Unrestricted grazing of goats must have severely suppressed natural regeneration of the forests. When the human population began cutting the mature trees for timber and fuel, deforestation was rapid. In 1683 the north-east of the island still supported endemic gumwood Commidendrum robustum forest over some 1,200 ha (Beatson 1816) but by 1778 fuelwood was in such short supply that the planting of gorse Ulex europaeus for fuel was ordered (Cronk $1986 \mathrm{~b})$. The maximum deforestation was probably reached in the mid to late nineteenth century, only 65 ha of woodland being recorded in 1884 (Morris 1884). It seems reasonable to assume that Wirebird numbers also reached their peak around this time.

The Wirebird: later history and developments

Some contraction of the species's range undoubtedly occurred after the establishment of a fibre industry based on New Zealand flax Phormium tenax in 1907. During this period up to $40 \%$ of the pastureland recorded in 1884 was given over to flax production (Brown 1981). The industry declined after the development of synthetic fibres and the last flax mill closed in 1966. Since then some of the flax plantations have been returned to pasture but many have been converted to forest so there has probably been a net loss of Wirebird habitat as a result of flax growing and its consequences.

Housing and amenity developments have also used former Wirebird breeding grounds, especially in the north-west of the island around Half-Tree Hollow and, to a lesser extent, in the Longwood area.

Throughout this period of dramatic environmental change the Wirebird is scarcely mentioned in the literature dealing with St Helena. The earliest specimens in the British Museum (Natural History) collection date from 1842; others were obtained by Layard in 1866 (Layard 1867). The bird was first described as a distinct species in 1873 (Harting 1873), but little information about its behaviour and ecology was obtained until 1984. St Helena's isolation has mitigated against thorough scientific investigation and most of the published data on the Wirebird are contained in the anecdotal writings of island residents (Baker 1868, Mellis 1871, Huckle 1924) or the observations of very short-term visitors (Moreau 1931, Benson 1950, den Hartog 1984). Significant contributions were, however, made by Haydock (1954), who spent three months on St Helena investigating the avifauna, identified II Wirebird breeding sites and made the first population estimate for the species; Pitman (1965), who described the eggs and some aspects of breeding behaviour, basing his account largely on the observations of local resident Arthur Loveridge; and Olson (1975), who treated the Wirebird as a component of his valuable study of the island's palaeornithology.

In 1984, following consultations with ICBP, where the Wirebird had been evaluated as deserving threatened species status, Alexander (1985) carried out the first specific field study of the Wirebird. This project was of four months' duration and provided much new information on distribution, breeding and social behaviour. 
Prior to the work of Alexander, estimation of Wirebird numbers tended to be based on subjective impressions rather than on systematic counts. Even Alexander's figure was based partly on extrapolation because of incomplete coverage. This has resulted in a disparity of estimates from which it is difficult to discern any recent trends.

Previous comments on population size include: "considerable numbers" (Beatson 1816); "not very numerous" (Baker 1868); "scarce without being rare" (Huckle 1924); "in considerable numbers" (Simmons 1927); "holding its own and breeding all over the island" (Moreau 1931); "not more than 100 pairs" (Haydock 1954); "just under a thousand" (A. Loveridge in Pitman 1965); "now relatively frequent" (Basilewsky 1970); "quite common" (Q. C. B. Cronk in Collar and Stuart 1985); "at least a few hundred individuals" (den Hartog 1984); "likely to be 200-300 birds, maximum" (L. Hepworth in Collar and Stuart 1985; also Alexander 1985).

It was largely this uncertainty over the numerical status of so isolated and perhaps vulnerable a species that led Collar and Stuart (1985) to treat the species as threatened and to recommend research on its population dynamics and ecology; they were of necessity unaware of the suggestion that there had been a serious decline in numbers during the last 30 years (Loveridge 1974), which might have lent greater immediacy to the call for an investigation. However, following the ICBP British Section's 1986 decision to support work on British Dependent Territories, a 14-month study was conducted to attempt to establish the true status of the Wirebird and to enlarge on Alexander's ecological work with a view to drawing up a conservation strategy for the species.

The study was carried out between October 1988 and December 1989. Its main objectives were to obtain an accurate estimate of population size by regular census work, to map the distribution of the Wirebird, to establish the species's major ecological requirements, and to identify any immediate threats.

\section{Methods}

\section{Census procedure}

All Wirebird sites referred to in the literature were visited between October and December 1988, as were any other areas having apparently suitable habitat on the basis of published data on the species's requirements. In effect this included all pastureland and all but the most heavily eroded and precipitous areas of the Crown Wastes (see below under Vegetation). The birds can be approached to around $20 \mathrm{~m}$ without causing serious alarm and are normally reluctant to take flight. This allowed direct counts to be used in censusing the population.

All sites where Wirebirds were found, or had been recently and reliably reported, were subsequently censused at three-month intervals. There were 31 regular census areas. Most of these had obvious topographical or vegetational boundaries but the extensive semi-desert areas of the north-east required the imposition of largely arbitrary divisions to enable them to be worked efficiently. Unoccupied sites were re-checked between census periods as other commitments allowed. The census areas are shown in Figure 1. The names used are taken from the current 1:25,000 map of St Helena (Directorate of Overseas 


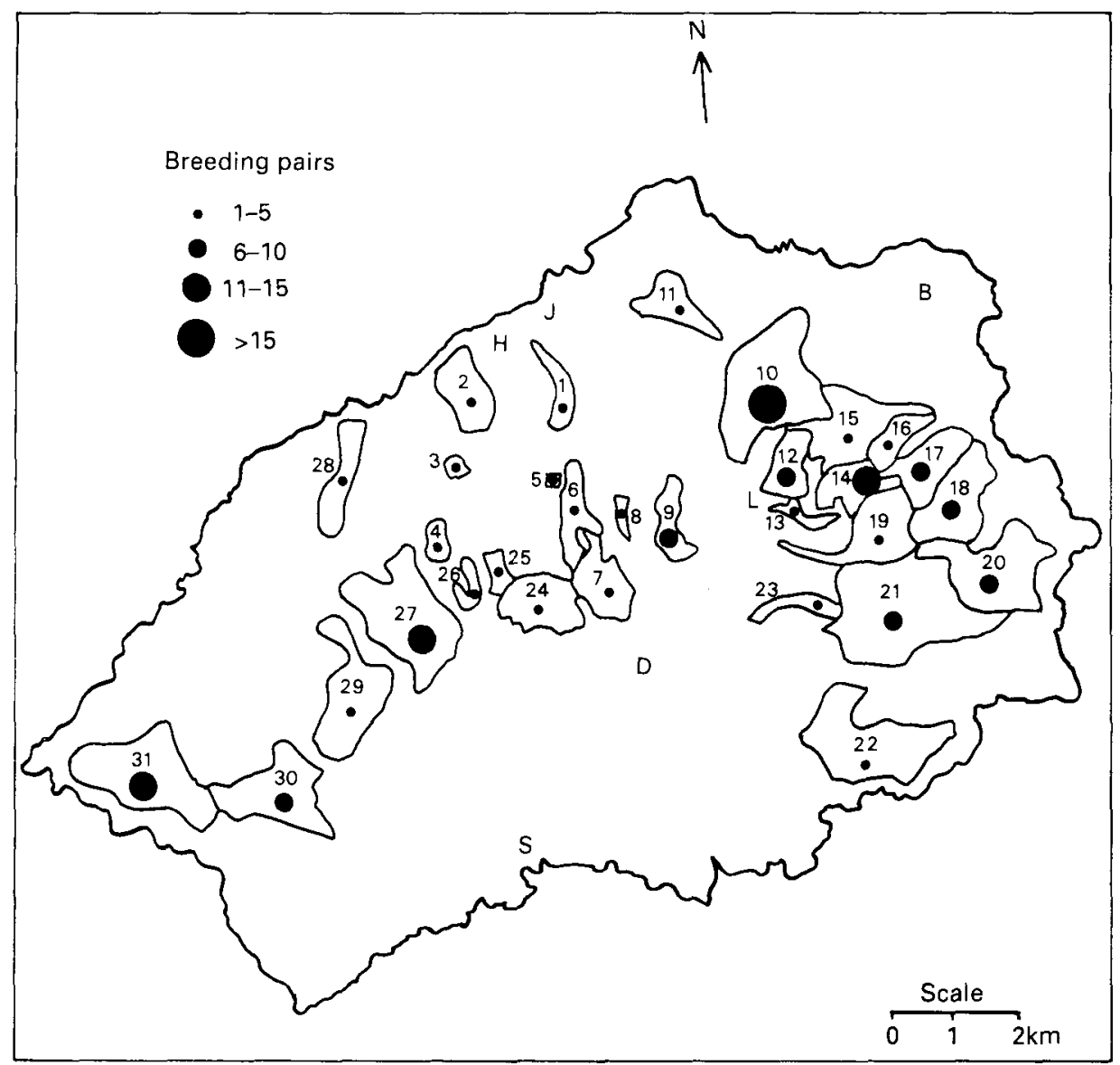

Figure 1. Map of St Helena showing Wirebird census areas (numbered), with estimated numbers of breeding pairs, and other principal localities mentioned in the text. Census areas (parentheses indicate names of convenience, see text): 1, Cow Path/High Knoll; 2, Donkey Plain; 3, Cleugh's Plain; 4, Rosemary Plain; 5, Francis Plain; 6, Barren Hill; 7, The Dungeon; 8, Prospect Pastures; 9, Sane Valley; 10, Deadwood Plain; 11, Bank's Ridge; 12, Longwood Farm; 13, Longwood Golf Course; 14, Bottom Woods; 15, (Longwood Erosion Zone); 16, (Weather Station Ridge); 17, Horse Point Plain; 18, (Prosperous Bay North); 19, Fisher's Valley; 20, Prosperous Bay Plain; 21, (Upper Prosperous Bay); 22, Stone Top Ridge; 23, Woody Ridge; 24, (Central Pastures); 25, Pounceys; 26, Oaklands Pastures; 27, Broad Bottom; 28, Horse Pasture; 29, Blue Hill/Head o' Wain; 30, (Southern Pastures); 31, Man and Horse. Other localities: B. The Barn; D, Diana's Peak; H, Half-Tree Hollow; J, Jamestown; L, Longwood; S, Sandy Bay.

Surveys 1983) except those in parentheses, which are names of convenience for census areas not covered by any single local name.

The method used in covering a site during census work depended on the size and topography of the site. At small sites all birds present could frequently be detected by walking round the periphery and scanning with $10 \times 40$ binoculars. On narrow ridges a walk down the mid-line often sufficed. At more extensive sites the area was covered in a series of transects, all birds in a strip extending 
$25 \mathrm{~m}$ on each side of the track being counted. As far as was possible, disturbance of birds within each strip was minimized. After becoming familiar with them, I found Wirebirds usually to be easily detectable as they tend to inhabit areas of low or sparse vegetation and are also highly vocal. It is unlikely that significant numbers were overlooked.

Birds in flight were not counted unless they were seen to take off from a part of the census area not yet covered.

Heavily gullied areas and all but the most open Opuntia scrub were not covered after the first census as there was no evidence of their regular use by Wirebirds, and the time required to survey such areas thoroughly was not justified by the relative increase in accuracy of the population estimate.

Initial investigation showed adult Wirebirds to be highly territorial and there was no evidence of regular large-scale movements between sites. Large numbers of Wirebirds frequently assembled at bathing and drinking sites at Cook's Bridge in Fisher's Valley and in lower Sheep Pound Gut. Birds at these sites were not included in the census as many appeared to be attracted there from relatively long distances and so were likely to have been counted elsewhere. Downy chicks were included in the counts.

\section{Breeding success}

Nest success Nests were located mainly during census work or other regular observations rather than by systematic searches. Because of lack of transport and commitments to other aspects of the study, it was rarely possible to visit individual nests regularly during incubation but most were visited at least three times. This allowed an estimate of nest success to be made. Nests were assumed to have failed if the nest was found to be empty before the eggs could have hatched or if no chicks of appropriate age were found within $100 \mathrm{~m}$ of the nest site and the parents failed to perform distraction displays on being approached.

Chick mortality Many more broods of chicks than nests were found during the course of the study. The number of chicks and their approximate age at the time of first location were recorded for each brood. As the body weight and growth rate of the Wirebird appear to be very similar to those of the Kentish Plover Charadrius alexandrinus, the criteria devised by Lessells (1984) for the latter species could be used to allocate chicks to two age classes. Those that were completely down-covered or weighed less than $20 \mathrm{~g}$ were assumed to be less than two weeks old; those which showed any feathering or weighed $20 \mathrm{~g}$ or more were assumed to be older than two weeks. This enabled a fairly crude assessment of chick mortality and its relation to age to be made. Chick mortality was also estimated from observations of colour-ringed chicks (see below).

Evidence of predation was recorded and the impact of various potential predators was subjectively assessed, as was the effect of disturbance of breeding birds by humans and livestock.

\section{Trapping and ringing}

As many Wirebirds as possible were marked with an individual combination of two or three plastic colour-rings (from A. C. Hughes Ltd, Hampton Hill, Mid- 
dlesex, U.K.) to obtain information on the movement of birds around the island. All birds were also fitted with a standard British Trust for Ornithology metal ring (size $\mathrm{B}+$, internal diameter $3.3 \mathrm{~mm}$ ) bearing an individual serial number. Normally two colour-rings were placed on the left leg and a metal ring, with a single colour above, on the right.

Most birds were caught by hand as chicks. Chicks are particularly easily caught during the first two weeks after hatching when their response to being approached is to lie down and remain motionless.

Adults were caught in a funnel trap on the nest. Trapping was only carried out under warm, dry conditions, to minimize the risk of the eggs becoming chilled. If a bird had not entered the trap after 20 minutes, trapping was abandoned and not attempted again at the same nest for several days, to reduce the possibility of desertion. Most birds were caught within 10 minutes of the trap being set. All trapped birds were seen to return to the nest after release and there was no evidence that any nest failed as a result of disturbance during trapping.

\section{Factors influencing distribution}

Wirebirds are not evenly distributed throughout St Helena. The major environmental factors influencing distribution are likely to be climate (particularly rainfall), topography (i.e. steepness of slope), vegetation type and food abundance. The density of Wirebirds at a particular site is the best available indicator of the overall suitability of the site, so the relationship between density and each of the above variables was investigated.

Density was estimated by dividing the mean number of birds counted at a site during the four censuses by the area of the site. The area was calculated from the 1:25,000 map of St Helena by scale drawing on squared paper. Area was estimated to the nearest 5 ha for sites larger than 10 ha, to the nearest 1 ha for smaller sites.

Climate Although St Helena lies well within the Tropic of Capricorn its climate is best described as subtropical. The most striking feature of the island's weather patterns is their variability, both temporally (between years) and spatially (within the island), so that the concept of a "typical" year has relatively little value. Temperatures are subject to the ameliorating influence of the South-East Trade Winds blowing over the cold Benguela current. Within the island, temperatures vary markedly with altitude. At Jamestown (sea level) the annual mean is $22{ }^{\circ} \mathrm{C}$ but at Hutt's Gate $(627 \mathrm{~m})$ only $16^{\circ} \mathrm{C}$. The coolest months are normally August and September and the warmest March and April.

The seasonal pattern and quantity of rainfall varies greatly between years. Precipitation increases with altitude: Jamestown receives, on average, less than $300 \mathrm{~mm}$ of rain annually but at an altitude of $800 \mathrm{~m}$ rainfall rises to over $900 \mathrm{~mm}$. In most years rainfall is heaviest between March and September.

Wind direction is dominated by the South-East Trades, which prevail on $70 \%-$ $80 \%$ of days, usually at a strength of Force $4-5$. Gales can be frequent between September and November.

The orographic disturbance of the prevailing airstream results in extensive cloud cover, especially at higher altitudes. At Hutt's Gate cloud cover averages over $80 \%$ throughout the year while at Jamestown Mathieson (1990) recorded 
variation between $46 \%$ and $82 \%$. Above $400 \mathrm{~m}$, low cloud can cause prolonged foggy conditions between March and November.

Relative humidity is typically $75 \%-85 \%$ but below the $900 \mathrm{~mm}$ isohyet, which approximately coincides with the $600 \mathrm{~m}$ contour, evapotranspiration generally exceeds rainfall (I. K. Mathieson pers. comm. 1989).

In this analysis it was only possible to investigate the influence of rainfall on Wirebird distribution as long-term data on other climatic factors were unavailable for most census areas.

Annual rainfall for each census area was estimated from a recent map of isohyets (Mathieson 1990) as the mean of the isohyet values within which the site lies. Mean Wirebird densities were regressed on these values.

The total area of all census sites was divided into five rainfall classes and the hypothesis that Wirebird distribution is unrelated to gradient was tested by the application of a G-test for goodness of fit (Sokal and Rohlf 1981) to the numbers of birds observed and expected in each class. Prior to testing, these figures were divided by three to allow for individual Wirebirds not being independently distributed, a substantial proportion of the population being found as territorial pairs or family parties, which would otherwise tend to increase the between-site variance and thus inflate the value of $G$. The creation of "pseudo-groups" of three in the analysis reduces this effect, although, since pairs and solitary birds greatly outnumber family groups, the G-value resulting from a "pseudo-group" size of three will be conservative. This method was also applied to similar Gtests for effects of gradient and vegetation type (see below).

Topography St Helena is of volcanic origin and is part of the Mid-Atlantic Ridge system, though it lies to the east of the main ridge. The island rises from a depth of 4,224 $\mathrm{m}$, having first emerged around 20 million years ago. The major axis is aligned north-east to south-west and is surmounted by a ridge rising to $823 \mathrm{~m}$ at Diana's Peak. The island comprises the remains of two shield volcanoes, one centred in the north-east of the island around Flagstaff Hill and the other in the Sandy Bay area (Daly 1927, Baker 1970).

Volcanic activity ceased around seven million years ago (Baker et al. 1967). Since then, fluvial erosion has been responsible for most of the present landforms (Nunn 1990). St Helena's topography is dominated by a radial drainage system centred on the central ridge. This has produced a series of steep-sided valleys, some up to $300 \mathrm{~m}$ deep, separated by generally narrow ridges. Between the valley mouths the coastline consists of cliffs ranging from $80 \mathrm{~m}$ to $570 \mathrm{~m}$ in height. Some of the bays have pebble or boulder beaches which are generally narrow.

The literature and initial field observations suggested that Wirebirds prefer relatively flat areas. An inverse relationship between bird density and gradient would be expected if this were the case.

An average gradient was calculated for each census area, again using the 1:25,000 map, by expressing the altitudinal increment along the axis of the dominant slope as a percentage of the horizontal distance. In the case of valley sites the mean of the constituent gradients was taken.

Vegetation The present vegetation of St Helena bears little relation to that occur- 
ring on the island at the time of its discovery in 1502. Since that date the indigenous plant communities have been almost entirely eradicated by the actions of man and his livestock, and replaced by a wide variety of introduced species. Cronk (1989) recognized eight present-day plant communities but these can be simplified into three altitudinal/climatic zones from which three vegetation types relevant to the Wirebird can be derived. In the following account nonindigenous species are denoted by an asterisk $\left({ }^{*}\right)$.

Below $350 \mathrm{~m}$ arid conditions prevail and the land surface has been subject to large-scale erosion. Such areas are designated the "Crown Wastes". On the eastern (windward) side of the island this zone comprises semi-desert, dominated by the shrub Suaedia helenae and large tracts of "creeper" Carpobrotus edulis*. On the western side, arid areas are typically covered by scrub dominated by either Lantana camara* or prickly pear Opuntia spp*. The eastern semi-desert region forms the first vegetation type.

In areas receiving less than $600 \mathrm{~mm}$ rain annually at intermediate altitudes (approximately $400-600 \mathrm{~m}$ ) the former range of the native gumwood Commidendrum robustum is now occupied by pastureland and non-indigenous woodland. The main pasture grasses in this zone, referred to in the analysis below as "Intermediate Pasture", the second vegetation type, are kikuyu grass Pennisetum clandestinum*, wire grass Cynodon dactylon* and Digitaria ciliaris*. The woods are predominantly of Acacia longifolia*, A. melanoxylon* and Pinus pinaster*.

On the steeper slopes above $500 \mathrm{~m}$, where the annual rainfall is between 600 and $1,000 \mathrm{~mm}$, the species composition of both pasture and woodland changes and large areas of land are still covered by relict plantations of New Zealand flax Phormium tenax*. Within this zone Brown (1981) recognized two types of grassland which she termed "moist" and "semi-moist". The former, found in areas with more than $900 \mathrm{~mm}$ of rain per year, is dominated by the grasses Agrostis tenuis $^{*}$ and $P$. clandestinum ${ }^{*}$ while in the latter mat grass Stenotaphrum secundatum $m^{*}$ is co-dominant with $P$. clandestinum ${ }^{*}$. These are considered together in this study as "Upland Pasture", the third vegetation type. Cape yew Podocarpus elongata* is a major tree species in the higher-altitude plantations.

Wirebirds avoid woodland and dense scrub. The open habitats they occupied fall into two broad classes: grassland and semi-desert. Mean Wirebird densities (log-transformed) were compared between these two classes by single-classification analysis of variance, using only sites larger than to ha. A further comparison was made between mean densities in intermediate and upland pasture. A G-test was also carried out on the observed and expected number of Wirebirds for the three vegetation types. The vegetational composition of 19 census areas was sampled using quadrats of $0.25 \mathrm{~m}$ area. The number of quadrats allocated to an area was equivalent to one quadrat/ha. At large sites quadrats were laid in subsets of 10 to 20 , which were distributed so as to ensure a fully representative coverage of the whole area: where more than one vegetation type was apparent within a census site, quadrats were allocated to each type in proportion to its area; within each subset the position of each quadrat was randomized. The direction taken and distance moved between individual quadrats were determined using a table of random numbers. Two series of numbers were used. The first, varying between 1 and 12 , determined direction from the starting point in terms of a clock-face. The second series, ranging from 1 to 100, indicated the 
number of paces to be moved. All species present within each quadrat were listed and the percentage of the total area covered by each species, or by bare earth or rock, was recorded. "Rock" includes bedrock, boulders and gravel of greater than $2 \mathrm{~cm}$ diameter. Finer gravels were included in "bare earth". The mean percentage cover was calculated for each species at all sites sampled.

At all sites at which quadrat sampling was carried out, the height of the vegetation was also measured at $0.5 \mathrm{~m}$ intervals along a $20 \mathrm{~m}$ line transect originating from the centre of every fifth quadrat.

It is difficult to investigate the effect of vegetation height on bird density by comparison of different sites, as elimination of other contributory factors is difficult. It was, however, possible to study the effect of varying vegetation height within a single census area (Deadwood Plain), thus largely controlling for other environmental parameters.

Deadwood Plain is grazed by cattle throughout the year. Grazing is rotated amongst a number of paddocks. During the dry season (approximately November-February) the combined effects of grazing and dehydration keep the grass uniformly short throughout the area. After the onset of the rains (usually around March) a mosaic of grass-lengths is produced, the mean length in any particular paddock being related to the time since it was last grazed.

Such mosaic conditions prevailed in April and May of 1989. In April the paddocks were subjectively classified as "long" or "short" with respect to grass length. Five paddocks were selected from each group, the total area covered by each category being approximately equal. Twenty-five random point measurements of grass length, to the nearest $1 \mathrm{~mm}$, were made in each paddock. Means were compared within groups by single-classification analysis of variance. In the absence of significant differences between paddocks the combined data for each group were used to compare group means. Wirebirds were counted in each paddock, at the same time of day, for nine consecutive days until the grazing regime was changed. Mean counts within groups were tested for differences between days and, as none was found, mean Wirebird numbers were compared between grass-length groups. The April group means were then compared with corresponding counts for the same areas obtained during the February census, when the grass was uniformly short, by means of a $t$-test (Sokal and Rohlf 1981) to investigate whether there had been any change of distribution associated with patterns of vegetation growth.

Food abundance The literature contains few references to the diet of the Wirebird. Layard (1867) examined the stomach contents of his specimens and found beetles (Coleoptera) and small snails (Gastropoda); Loveridge (1974) recorded a Wirebird taking various immobilized insects after heavy rain; den Hartog (1984) was able to confirm that small snails were taken; and Alexander (1985) reported large beetles frequently being caught.

All identifiable prey items seen to be taken by Wirebirds during this study were recorded and the relative abundance of ground-living invertebrates at a number of Wirebird breeding sites was estimated by regular pit-fall trapping. At each trapping site a $4 \times 3$ grid of 12 pots (plastic drinking cups) spaced at $5 \mathrm{~m}$ intervals was used. In the largest census areas up to three such grids were operated simultaneously. Trapping was carried out at 15 sites but regular sampling (one grid unless stated) was confined to Barren Hill (two grids), Deadwood 
Plain (three grids), Bottom Woods, Horse Point Plain and Broad Bottom (two grids), which were used every month in 1989, and Longwood Farm and Prosperous Bay Plain (three grids), where trapping was bimonthly. Analysis is confined to these seven sites. Within each month three consecutive 24 -hour samples were taken, the mean being used in this analysis to reduce any effect of variation in catches between days caused by climatic conditions. Collembola were excluded from the analysis as their occurrence in the traps was more heavily influenced by climatic conditions than any other species and their extremely small size $(<1 \mathrm{~mm})$ makes them unlikely to be significant Wirebird prey.

Pit-fall catches can be affected if the hole for each pot has to be re-dug after every sample is removed. To avoid this, the trapping pot was placed inside another, which formed a jacket into which the trap pot could be replaced without the soil being disturbed. All pots were removed between trapping periods and the positions of the holes were marked to aid relocation.

The effect of rainfall on invertebrate abundance was investigated by regression of the mean daily catch for each month on monthly rainfall at the nearest recording station. This was done for all monthly sampling sites, using data for the period January-November 1989.

If there is an overall seasonal pattern of invertebrate abundance on St Helena then the relative size of monthly catches should show similarity between sites. This hypothesis was tested by ranking the monthly catches at each grid where trapping was carried out every month and using these ranks to calculate Kendall's coefficient of concordance $(w)$.

An index of relative invertebrate abundance was calculated by using the mean daily catch for the year at Deadwood Plain as a reference value and dividing the mean catches at other sites by this figure. In calculating the mean catch for each site the data for all trap grids within the site were combined. An index of beetle abundance was calculated similarly. These indices were used to investigate the relationship between Wirebird density and prey abundance. Bird density was regressed on the indices for all species and for beetles from the seven regularly sampled sites.

\section{Results}

\section{Census}

Counts obtained in all census areas are presented in Table 1 with means and standard deviations (s.d.). The total count ranged from 389 to 495 birds, with a mean of 447 (s.D. 47.8 ).

Wirebirds are patchily distributed throughout the island. Most are concentrated in the north-east quarter (Figure 1), approximately $75 \%$ of the total being found between Sane Valley and Prosperous Bay Plain. Deadwood Plain is by far the most important site, holding around $30 \%$ of the population. No other single site holds more than $10 \%$ of the total. Other major sites are Bottom Woods, the south-western sheep pastures (especially Man and Horse), and the whole of the arid region including Horse Point Plain, Prosperous Bay North, Prosperous Bay Plain and Upper Prosperous Bay. No Wirebirds were found in the area south of the central ridge.

Sites at which Wirebirds had been previously recorded but in which they were 
Table 1. Censuses of Wirebird populations. Census area numbers correspond to those in Figure 1

\begin{tabular}{|c|c|c|c|c|c|c|}
\hline $\begin{array}{l}\text { Census } \\
\text { area }\end{array}$ & $\begin{array}{l}\text { Count I } \\
\text { (Oct-Nov } \\
1988)\end{array}$ & $\begin{array}{c}\text { Count } 2 \\
\text { (Feb-Mar } \\
\text { 1989) }\end{array}$ & $\begin{array}{c}\text { Count } 3 \\
\text { (Jun-Jul } \\
1989\end{array}$ & $\begin{array}{c}\text { Count } 4 \\
\text { (Oct-Nov } \\
1989 \text { ) }\end{array}$ & Mean & S.D. \\
\hline 1 & - & - & 0 & 2 & 1 & 1.41 \\
\hline 2 & 4 & 2 & 5 & 4 & 4 & 1.26 \\
\hline 3 & 2 & o & o & o & 1 & 1.00 \\
\hline 4 & o & 3 & 3 & 2 & 2 & 1.41 \\
\hline 5 & 2 & 1 & 6 & 3 & 3 & 2.16 \\
\hline 6 & 13 & 9 & 7 & 6 & 9 & 3.10 \\
\hline 7 & o & 2 & 2 & 2 & 2 & 1.00 \\
\hline 8 & 5 & o & o & o & 1 & 2.50 \\
\hline 9 & 12 & 19 & 13 & 14 & 15 & 3.11 \\
\hline 10 & 129 & 147 & 150 & 121 & 138 & 14.01 \\
\hline 11 & 6 & 6 & 6 & 12 & 8 & 3.00 \\
\hline 12 & 13 & 22 & 15 & 17 & 17 & 3.86 \\
\hline 13 & 18 & 7 & 16 & 6 & 12 & 6.13 \\
\hline 14 & 37 & 53 & 40 & 47 & 44 & 7.18 \\
\hline 15 & 6 & 6 & 7 & 5 & 6 & 0.82 \\
\hline 16 & 2 & 6 & 7 & o & 4 & 3.30 \\
\hline 17 & 20 & 13 & 20 & 21 & 19 & 3.70 \\
\hline 18 & 24 & 6 & 17 & 19 & 17 & 7.59 \\
\hline $19^{\mathrm{a}}$ & 1 & 2 & 0 & 4 & 2 & 1.71 \\
\hline 20 & 14 & 9 & 43 & 20 & 22 & 15.02 \\
\hline 21 & 15 & 10 & 26 & 29 & 20 & 8.98 \\
\hline 22 & - & - & 4 & 6 & 5 & 1.41 \\
\hline 23 & 2 & 1 & 0 & 13 & 4 & 6.06 \\
\hline 24 & I & $I$ & o & 0 & 1 & 0.58 \\
\hline 25 & 5 & 2 & 1 & 4 & 3 & 1.83 \\
\hline 26 & 2 & 5 & 5 & 1 & 3 & 1.06 \\
\hline 27 & $19^{b}$ & 38 & 42 & 38 & 34 & 10.34 \\
\hline 28 & II & 6 & 9 & 8 & 9 & 2.08 \\
\hline 29 & 0 & 4 & 5 & 4 & 3 & 2.22 \\
\hline 30 & $3^{b}$ & 16 & 13 & 20 & 13 & 7.26 \\
\hline 31 & 23 & 31 & 33 & $47^{c}$ & 34 & 9.98 \\
\hline Total & 389 & 427 & 495 & 475 & 447 & 47.79 \\
\hline No. chicks & 26 & 10 & 9 & 17 & & \\
\hline \multicolumn{5}{|c|}{ Mean total, based on counts $2,3,4$ only } & 466 & 34.95 \\
\hline
\end{tabular}

-, not covered; ${ }^{a}$, excluding Cook's Bridge; ${ }^{b}$, poor visibility; ${ }^{c}$, census area extended.

not seen in 1988-1989 were Fairyland, High Hill (Ebony Plain), White Hill/Sandy Bay Barn, High Ridge, The Barn and Crack Plain. Non-resident Wirebirds were encountered outwith the census areas at Ladder Hill, Plantation House, Knotty Ridge, Jamestown Wharf (in flight) and in various gardens in the Alarm Forest area.

The best estimate of the current Wirebird population from direct counts is the mean of the second, third and fourth censuses. This gives a figure of 466 birds. If it is assumed that, within the census areas, birds overlooked and those counted more than once approximately cancel out and that around 20 birds can be added to allow for those omitted at the bathing sites or undetected elsewhere, then the estimate approaches 500 birds. 


\section{Potential sources of error in the counts}

Some error is likely to have arisen from birds being overlooked or counted more than once within sites. It is not possible to quantify the scale of such error but the relative consistency of counts at major sites between census periods suggests that it is not a serious problem.

Birds which move between census areas may be counted more than once but, equally, may be missed completely, so this introduces imprecision rather than bias. Observations of marked birds indicate that adults tend to be sedentary, so any error is likely to involve juveniles, which make up only some $10 \%$ of the population at any one time. Influxes of more than two juveniles are rare at most sites and are usually readily detectable.

Although birds attending the two major bathing sites were excluded from the census because they were known to include many that had "commuted" from neighbouring census areas, it is almost certain that some previously undetected birds were omitted as a result.

Some birds probably remained undetected in heavily eroded or scrub-covered areas not included in the census sites. There may be as much as 400 ha of such country containing some potential Wirebird habitat. If it is assumed that Wirebirds occur within this area at a similar density to those in the Longwood Erosion Zone ( $0.05 / \mathrm{ha})$, this would provide an additional 20 birds.

The above factors apply to all censuses but there may have been particular sources of inaccuracy in the first and third counts. It is probable that the total for the initial census substantially underestimates the true population, mainly because I was unfamiliar with the Wirebird and its calls. During the June 1989 census a large hatch of caterpillars associated with the shrub Suaedia helenae occurred in the arid zone of the north-east, particularly at Prosperous Bay Plain. The number of Wirebirds feeding on caterpillars at this site was three times greater than the highest previous count for the area and it seems certain that birds had been attracted from other sites, so the problem of double-counting or missing mobile birds was more marked on this than other censuses.

\section{Breeding success}

Nest success Wirebirds were found to breed throughout the year, but most nested in the October-March dry season (Figure 2), normally producing a clutch of two eggs. A single-egg clutch was laid in only one of the nests recorded during this study. Of the 43 nests recorded, 11 were successful (i.e. resulted in at least one hatched chick), 15 failed and the outcome of 17 was unknown.

In the absence of predation hatching success is high (95\%). It is impossible to give an accurate estimate of egg-loss resulting from predation because the age of most clutches at the time of finding was unknown. It was, therefore, not possible to know whether missing eggs had been taken or the chicks had died or been taken after hatching. The area around empty nests was searched for shell fragments but these were extremely difficult to find.

Observations of marked birds during this study showed that Wirebirds may lay more than one clutch in a year. Two females that were known to have successfully reared at least one chick from their previous clutch laid again after 


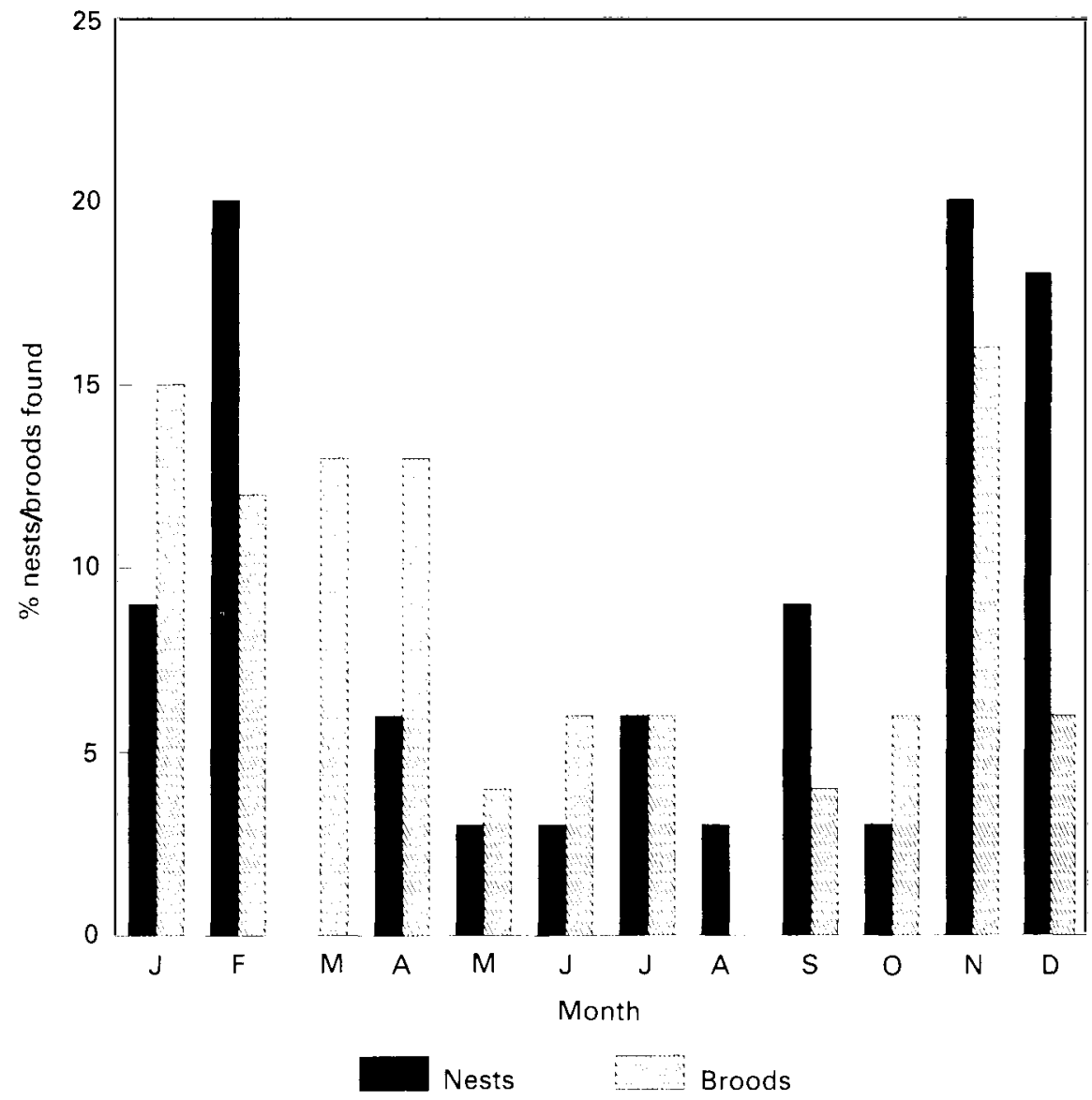

Figure 2. Timing of breeding by Wirebirds: monthly distribution of nests and broods found during 1989 expressed as percentages of totals for the year.

intervals of approximately 80 days and 230 days respectively. Another female relaid after 320 days but is suspected to have attempted at least one other clutch in the intervening period. This last bird retained the same mate throughout but it is not known if this was true in the other two instances. Wirebirds will produce a replacement clutch if eggs or chicks are lost. A pair that lost eggs were observed performing a mating display near their previous nest site within 24 hours. Another pair which lost chicks were seen copulating around 25 days later.

Chick mortality Of the 78 broods found during this study only $46 \%$ were of two chicks. Assuming that the proportions of single-egg clutches (2\%) and eggs failing to hatch $(5 \%)$ in observed nests that produced at least one chick are representative of the population as a whole, this gives an estimate of posthatching mortality of $22 \%$. This, of course, takes no account of either broods which hatched but were not detected because both chicks were lost or of any subsequent loss from recorded broods. The true mortality rate is therefore likely to be considerably higher and this is borne out by the results of colour-ringing.

Comparison of the fledging success of chicks colour-ringed within two weeks 
of hatching and those ringed when older suggested that the highest mortality occurred in the first two weeks. Of those chicks ringed when less than two weeks old $16 \%$ were known to have survived to independence whereas a minimum of $35 \%$ of older chicks fledged successfully, although this difference was not statistically significant $(\mathrm{G}=3.01,1 \mathrm{df})$. In all, 15 of 64 ringed chicks were re-sighted when fledged and independent of their parents, giving a minimum fledging rate of $23.4 \%$. Combining the estimated rates of nest success, hatching and fledging given above produces an estimate of survival from egg to independent juvenile of $19 \%$. This is almost certainly an overestimate.

\section{Predation}

The previous section showed that pre-fledging mortality in the Wirebird is high. Predators certainly cause some loss of eggs and chicks but the exact proportion is not known: no clues to the cause of failure were ever found at nests. There may also be some predation of fully grown birds but again the scale of this is unclear and only circumstantial evidence was found during my study. Three Wirebirds with injured legs and another with a broken wing were encountered on Longwood Golf Course, the Wirebird site most frequented by cats and dogs, during the 14 months of fieldwork. A further injured bird was found at Bank's Ridge. All but one of these casualties were juveniles, which might be more vulnerable to predators than experienced adults.

The potential predators of the Wirebird and/or its eggs are cats Felis domesticus, dogs Canis familiaris, rats Rattus spp., mice Mus musculus and Common Mynas Acridotheres tristis.

Cats Cats became established on St Helena within 150 years of the island's discovery and were found to be numerous by Peter Mundy in 1634 (Temple 1914). They are now widespread, the greatest numbers occurring around the larger settlements. There are probably relatively few truly feral cats but large numbers of domestic pets wander freely.

Cats probably have their greatest impact on the Wirebird in the areas surrounding Longwood, Deadwood and Bottom Woods settlements, where a large number of domestic cats live near substantial Wirebird populations.

Cats are probably the only predator of fledged Wirebirds. A Wirebird carcass found on the golf course had injuries consistent with its having been killed by a cat. If, however, predation of full-grown birds was severe one would expect to find carcasses more often. It is probable that cats take significant numbers of chicks in some areas and I received one report from a usually reliable source that a cat had been seen to take Wirebird eggs.

The Public Health Department occasionally traps cats but the effort is centred on Jamestown and Half-Tree Hollow, and so is of little significance to Wirebird protection. Some trapping is done at Longwood but financial constraints prevent this being carried out more regularly. Only cats without any mark of ownership are destroyed and it is unlikely that numbers are much reduced. Information on the number of cats trapped in specific areas is not available.

Dogs Dogs have been present on St Helena for a similar length of time to cats and are numerous throughout the island, especially around settlements. Intensive 
shooting campaigns in recent years have greatly reduced the number of feral dogs on the island but some still exist. Little control is exercised over a large proportion of domestic pets, however, and these roam widely. Small packs were often encountered in various parts of the island.

Predation by dogs on Wirebirds is likely to be confined to chicks and eggs. No direct evidence was found but dogs were seen to chase adult Wirebirds on the golf course and the consumption of eggs has been reported.

Rats Two species of rat occur on St Helena. The black rat Rattus rattus was possibly the earliest mammalian colonist of the island after its discovery by man in 1502 but as much as 200 years may have elapsed before it was joined by the larger brown rat $R$. norvegicus (Atkinson 1985).

The numbers of rats on St Helena have occasionally reached plague proportions. This seems to have occurred frequently in the hundred years after 1650 (Gosse 1938) but in more recent times continuous poisoning appears to have suppressed the population to some degree. Rats are still widespread and common, however. The greatest numbers encountered outwith the settlements were found in densely vegetated road verges and around the margins of flax plantations. Rats appeared to be scarce at most grassland Wirebird sites and absent from the most arid areas, but the true situation is unknown. Sightings or other evidence of rats (e.g. droppings) on pastureland were obtained at Deadwood Plain, Broad Bottom, The Dungeon, Barren Hill and Blue Hill. Two Wirebird sites, Horse Point Plain and Donkey Plain, are adjacent to rubbish dumps, which are likely to harbour large numbers of rats.

Because of its more terrestrial lifestyle, the brown rat is likely to pose the greater threat to Wirebirds (Atkinson 1985). It is highly probable that rats take eggs and are certainly capable of killing chicks, though evidence is lacking.

Mice The house mouse is another long-established colonist of St Helena. Mice are extremely abundant at all Wirebird sites and, in the absence of significant predation, are active throughout the daylight hours. In other parts of the world mice have been found to eat the eggs of ground-nesting birds (Maxson and Oring 1978). No evidence of this was found at any of the failed nests recorded during this study but the possibility remains. As a testimony to their omnivory, mice have been implicated in the decline of endemic snails Succinea spp. and the giant earwig Labidura herculeana on St Helena (Clarke 1990).

Mynas The Common Myna is a relatively recent addition to the fauna of St Helena, though the exact date of its introduction is uncertain. The present population is probably descended from a number of birds released in 1885 (Basilewsky 1970). Mynas were originally introduced with the intention of controlling cattle ticks. The population has increased rapidly and the species is now amongst the commonest birds on the island. It is an omnivorous opportunist and any small success its introduction has achieved in controlling pests of cattle is probably at least balanced by its depredations on fruit trees and other crops.

Mynas are known to raid the nests of other small birds and, occasionally, of their own species (Loveridge 1974). It is likely, therefore, that they will take the eggs of Wirebirds, should the opportunity present itself. The reaction of Wire- 
birds at the nest or with chicks towards Common Mynas in the vicinity is stronger than that towards any other birds, suggesting that they are perceived as a threat.

During this study Common Mynas were seen to approach five nests and seven broods. In all cases the parents either performed distraction displays or attacked. The response of individual Wirebirds varied in intensity. Some would simply follow any myna within $10 \mathrm{~m}$ of the nest or position themselves between the myna and the nest; but any approach within $5 \mathrm{~m}$ of the nest would provoke display or aggression. Alexander (1985) observed similar behaviour. If a nest was left unoccupied during interactions with mynas the eggs were always covered - the usual reaction to potential predators (similar to the egg-hiding behaviour of Kittlitz's Sand-plover, for which see Cramp and Simmons 1983). Despite these observations no positive proof of nest robbery by mynas was found. I suspect that this may be relatively common, however.

Mynas were found at all Wirebird breeding sites but were particularly common on pastureland where they frequently feed on invertebrates disturbed by cattle (McCulloch in prep.). The Common Myna is the Wirebird's only avian competitor of terrestrial invertebrate prey but the extent of this competition has yet to be quantified.

\section{Disturbance}

Disturbance by man Regular disturbance of breeding birds by people has been shown to result in reduced fledging success in some plover species by reducing the feeding and brooding time available to the chicks (e.g. Flemming et al. 1988). Disturbance of Wirebirds can arise from the use of breeding areas by walkers, passage of motor vehicles (though Wirebirds are considerably more tolerant of vehicles than of persons on foot), and from crop husbandry. The last only affects birds at Broad Bottom, Longwood Farm and, to a lesser extent, Woody Ridge.

It was not possible to carry out a detailed investigation of the effects of disturbance in the time available but a subjective assessment of the average level of disturbance at each Wirebird site, based on personal experience, was made. This is presented in Table 2.

Despite St Helena's small size and relatively large human population, few Wirebird sites are subject to serious disturbance. The worst affected are Francis Plain, Longwood Golf Course, the lower parts of Deadwood Plain around Deadwood village, and Horse Pasture.

High levels of disturbance affect less than $5 \%$ of the breeding population and successful fledging is known to have occurred at all the worst affected sites except Francis Plain during 1988/1989.

Disturbance by livestock Wirebirds generally show no fear of cattle or other grazing animals, often allowing them to approach within $2 \mathrm{~m}$ without any sign of alarm. They rarely forage where livestock are concentrated, however. Adult Wirebirds were occasionally seen to perform distraction displays when cattle came very close to nests or chicks, though with little effect. Egg-covering in response to the approach of livestock was never observed.

The major threat posed to ground-nesting birds by livestock is that of nest- 
Table 2. Estimated human disturbance in Wirebird census areas

\begin{tabular}{|c|c|c|c|}
\hline & Pedestrians & Vehicles & Crop husbandry \\
\hline High Knoll/Cowpath & 4 & B & - \\
\hline Donkey Plain & $2-4$ & B & - \\
\hline Rosemary Plain & $2-4$ & B & * \\
\hline Francis Plain & 4 & A & - \\
\hline Barren Hill & 2 & - & - \\
\hline Prospect pastures & 2 & - & - \\
\hline The Dungeon & 2 & - & - \\
\hline Sane Valley & 3 & - & - \\
\hline Deadwood Plain (lower) & 4 & B & - \\
\hline Deadwood Plain (upper) & $1-2$ & A & - \\
\hline Bank's Ridge & 1 & A & - \\
\hline Longwood Farm & 2 & A & * \\
\hline Longwood Golf Course & 4 & - & - \\
\hline Bottomwoods & 3 & A & - \\
\hline Longwood Erosion Zone & 1 & - & - \\
\hline Weather Station Ridge & 2 & - & - \\
\hline Horse Point Plain & 2 & A & - \\
\hline Prosperous Bay North & 1 & - & - \\
\hline Fisher's Valley & 3 & A & - \\
\hline Prosperous Bay Plain & 2 & A & - \\
\hline Upper Prosperous Bay & 1 & - & - \\
\hline Woody Ridge & 3 & A & * \\
\hline Stone Top Ridge & I & - & - \\
\hline Central Pastures & $2-3$ & - & - \\
\hline Pounceys & 4 & A & - \\
\hline Oaklands Pastures & 2 & - & - \\
\hline Broad Bottom & $1-3$ & B & * \\
\hline Horse Pasture & $1-4$ & B & - \\
\hline Blue Hill/Head o'Wain & 2 & - & - \\
\hline Southern Pastures & $1-3$ & B & - \\
\hline Man and Horse & 1 & A & - \\
\hline
\end{tabular}

Key: $1,<1$ person per day; $2,1-5$ persons per day; $3,6-10$ persons per day; $4,>10$ persons per day. $A,<$ daily, but regular; B, daily; *, regular.

trampling. None of the failed nests that were examined showed discernible signs of this, but studies of nesting waders in Holland and England have shown that trampling by cattle, at a grazing density of one cow per acre, can destroy $40 \%$ to $60 \%$ of nests (Beintema 1982, O'Connor and Shrubb 1986). During the 1988-1989 dry season grazing densities within individual paddocks at Deadwood Plain occasionally exceeded 12 cows per acre. However on such occasions the entire Deadwood herd (c. 90 head) was confined to one paddock and around $90 \%$ of the Plain remained ungrazed.

\section{Movements}

Observations of marked birds indicated that adults, having once bred, tend to be sedentary. Only two out of 11 ringed adults were ever found at a census area other than that in which they were ringed and all re-sightings of others were 
within $200 \mathrm{~m}$ of their previous nest sites. These sedentary birds were all seen regularly.

Juveniles were more likely to move than adults. Seven $(47 \%)$ of the ringed juveniles that survived to become independent were found outside their natal areas, though one later returned to breed. Further evidence of the greater mobility of juveniles comes from several observations at various sites of small groups of young birds which stayed only a short time to feed before moving on; in contrast, the location of paired adults within sites was frequently predictable over long periods of time.

The only indications of any seasonal movement were in the north-east of the island where the number of Wirebirds found at arid sites during the February 1989 census was only half that found in October 1988, suggesting an exodus in response to drought conditions. This interpretation was supported by a corresponding increase in Wirebird numbers at adjacent grassland sites. By June, after the start of the wet season, numbers on the Crown Wastes had risen again, though they were probably inflated by the attraction of the caterpillar hatch described above. There was a parallel reduction in numbers at grassland sites, though by an amount insufficient to explain all of the increase on the Crown Wastes. It is not known if such distributional changes occur annually but it has been suggested that similar movements took place during the drought of 1984 (L. Hepworth in Alexander 1985).

\section{Factors influencing distribution}

Rainfall No correlation between Wirebird density and annual rainfall was found $(r=0.03, n=29)$. However, this analysis assumes a linear relationship, and application of a G-test to the numbers falling into five rainfall classes showed a significant excess of birds in areas receiving between 300 and $700 \mathrm{~mm}$ rain annually (Table 3a). The most favoured areas, between the 300 and $500 \mathrm{~mm}$ isohyets, hold $72 \%$ more Wirebirds than would be expected if distribution were random.

Topography Regression of population density on gradient at sites larger than to ha revealed a significant inverse correlation $(r=-0.41, P<0.05, n=29)$. The addition of a quadratic term significantly strengthened the relationship, explaining $33 \%$ of the variation in density (Figure 3 ).

The G-test revealed a highly significant non-random distribution (Table $3 \mathrm{~b}$ ). Sites with a gradient of less than $6 \%$ held an excess of birds and all other classes held fewer than expected. The analysis is fairly crude and fails to take into account the tendency of Wirebirds at sites with a high mean gradient to congregate on the flatter parts. Thus the effective area of many census sites is considerably smaller than that delimited by apparently suitable vegetation. These results do, however, support the hypothesis that Wirebirds find areas with a gradient greater than $10 \%$ relatively unattractive.

Vegetation The mean Wirebird densities for grassland and semi-desert were 0.29 birds/ha and $0.09 \mathrm{birds} / \mathrm{ha}$ respectively. These differ significantly at the $5 \%$ level: 
Table 3. Wirebird distribution in relation to rainfall, gradient and vegetation type. G-values are calculated using actual numbers divided by three to correct for non-independent distribution of Wirebirds (see text)

\begin{tabular}{|c|c|c|c|}
\hline & & \multicolumn{2}{|c|}{ No. Wirebirds } \\
\hline & & Observed & Expected \\
\hline \multirow[t]{7}{*}{ (a) } & Annual rainfall (mm) & & \\
\hline & $<300$ & 65 & 163 \\
\hline & $300-500$ & 268 & 156 \\
\hline & $501-700$ & 73 & $5^{1}$ \\
\hline & $701-900$ & 48 & 71 \\
\hline & $>900$ & 1 & 13 \\
\hline & & & $3, P<0.001$ \\
\hline \multirow[t]{8}{*}{ (b) } & Mean gradient (\%) & & \\
\hline & $0-5$ & 174 & 77 \\
\hline & $6-10$ & 111 & 115 \\
\hline & $11-15$ & 55 & 115 \\
\hline & $16-20$ & 74 & 81 \\
\hline & $21-25$ & 13 & 34 \\
\hline & $26-30$ & 28 & 33 \\
\hline & & & $3, P<0.001$ \\
\hline \multirow[t]{5}{*}{ (c) } & Vegetation type & & \\
\hline & Intermediate pasture & 281 & 139 \\
\hline & Upland pasture & 56 & 94 \\
\hline & Semi-desert & 101 & 205 \\
\hline & & & $1, P<0.001$ \\
\hline
\end{tabular}

$F(1,24)=4.45$. Within the grassland there was also a significant difference between the mean density on intermediate pastures ( $0.36 \mathrm{birds} / \mathrm{ha}$ ) and that on upland pastures ( 0.13 birds/ha) at the $5 \%$ level: $F(1,15)=5.90$. Although closely resembling intermediate pastures in species composition the Longwood Golf Course was excluded from this analysis because of the atypical variability of Wirebird numbers at this site. Its inclusion would have strengthened both differences.

Further evidence of a preference for intermediate pasture was provided by the result of a G-test carried out on the observed and expected numbers of Wirebirds for the three vegetation types. The observed distribution was significantly nonrandom, the total number of Wirebirds on intermediate pasture being twice that expected, with fewer than expected being found in the other classes (Table $3 \mathrm{c}$ ).

Linear regression of Wirebird density on pastureland components revealed significant positive relationships with percentage kikuyu grass and percentage broadleaved weeds $(r=0.58, P<0.05$ and $r=0.92, P<0.001)$. The slopes of the relationships with Agrostis tenuis, mat grass and cow grass were negative but not significant. There was also a positive correlation between density and percentage bare earth $(r=0.84, P<0.001)$. Mean coverage by hay grass was significantly greater on upland sites while broadleaved weeds and bare earth occurred over a greater area of intermediate pastures (Table 4 ).

The vegetational composition of semi-desert areas (Crown Wastes) is presented in Table 5 . There is little species overlap between these areas and pasture- 
Table 4. Mean percentage covered by major vegetational components in intermediate and upland pastures and mean height of vegetation in each habitat, with results of comparison by single classification analysis of variance

\begin{tabular}{lccc}
\hline & $\begin{array}{c}\text { Intermediate } \\
\text { pastures (mean) }\end{array}$ & $\begin{array}{c}\text { Upland } \\
\text { pastures (mean) }\end{array}$ & $F(1,11)$ \\
\hline $\begin{array}{l}\text { Kikuyu grass } \\
\text { Pennisetum clandestinum }\end{array}$ & 38.2 & 49.6 & 1.69 \\
Mat grass & 9.6 & 9.4 & 0.00 \\
Stenotaphrum secundatum & & & \\
Hay grass & 0.5 & 13.6 & $12.16^{* *}$ \\
Agrostis tenuis & & & \\
Wire grass & 3.2 & 0.5 & 4.04 \\
Cynodon dactylon & 0.4 & 5.2 & 4.06 \\
Cow grass & 60.1 & 87.9 & $6.33^{*}$ \\
Paspalum scrobiculatum & 12.6 & 4.4 & 3.69 \\
All grasses & 20.5 & 3.7 & $6.15^{*}$ \\
Broadleaved weeds & 7.0 & 9.9 & $8.82^{*}$ \\
Bare earth & & & \\
Vegetation height & & &
\end{tabular}

${ }^{*} P<0.05,{ }^{* *} P<0.001$

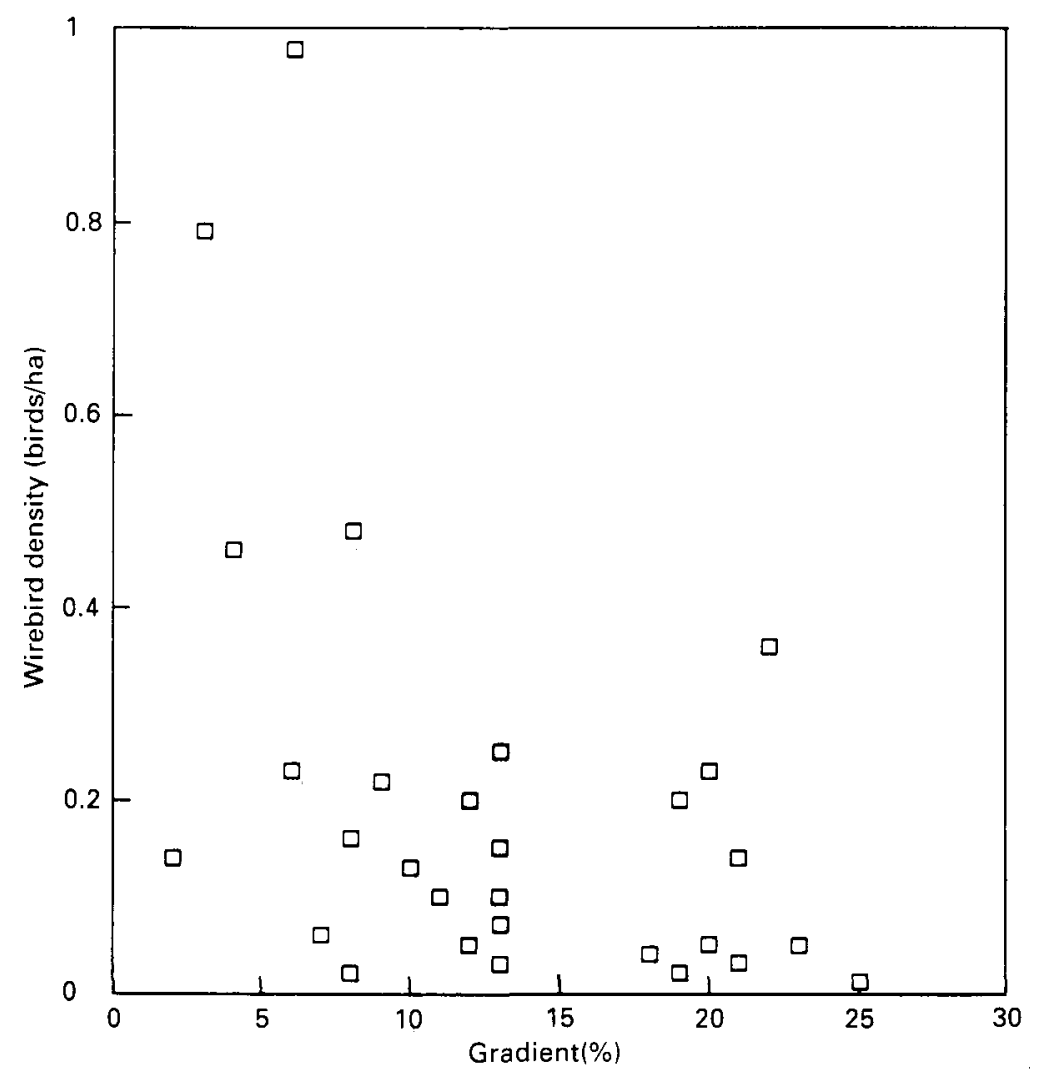

Figure 3. Relationship between mean Wirebird density and mean gradient in 29 census areas of more than 10 ha. 
Table 5. Vegetational composition of Wirebird sites in the Crown Wastes

\begin{tabular}{|c|c|c|c|c|c|}
\hline & \multicolumn{5}{|c|}{ Percentage cover } \\
\hline & $\mathrm{BR}$ & HPP & PBN & PBP & UPB \\
\hline \multicolumn{6}{|l|}{ Creeper } \\
\hline Carpobrotus edulis (live) & 7.0 & 14.2 & $7 \cdot 7$ & 5.2 & $19 \cdot 5$ \\
\hline \multicolumn{6}{|l|}{ Creeper } \\
\hline Carpobrotus edulis (debris) & 9.5 & $24 \cdot 4$ & 11.9 & 6.3 & 11.8 \\
\hline Atriplex semibaccata & 2.7 & 6.7 & 2.4 & 5.2 & 6.9 \\
\hline Suaedia helenae & 2.4 & 0.0 & 6.7 & 5.8 & 8.0 \\
\hline Eragrostis cilianensis & 0.0 & 0.0 & 0.5 & 3.1 & 1.5 \\
\hline Broadleaved weeds & 0.6 & 0.6 & 1.0 & 0.9 & 0.1 \\
\hline \multicolumn{6}{|l|}{ Ice plant } \\
\hline Mesambryanthemum crystallinum & 0.1 & 0.6 & 0.9 & 0.1 & 1.5 \\
\hline \multicolumn{6}{|l|}{ Prickly pear } \\
\hline Opuntia spp. & 0.3 & 0.4 & 0.3 & 0.0 & 0.4 \\
\hline \multicolumn{6}{|l|}{ Wild coffee } \\
\hline Chrysanthemoides monilifera & 1.3 & 0.0 & 0.0 & 0.0 & 0.1 \\
\hline \multicolumn{6}{|l|}{ Baby's toes } \\
\hline Hydrodea cryptantha & 0.0 & 0.0 & 0.0 & 0.1 & 0.0 \\
\hline \multicolumn{6}{|l|}{ Lantana } \\
\hline Lantana camara & 0.1 & 0.0 & 0.0 & 0.0 & 0.0 \\
\hline Lichens & 2.0 & 0.3 & 1.3 & 1.4 & 1.5 \\
\hline Bare earth & 58.0 & 39.2 & 55.1 & $44 \cdot 1$ & $37 \cdot 3$ \\
\hline Rock & 14.8 & $13 \cdot 7$ & 12.7 & 28.1 & 10.7 \\
\hline
\end{tabular}

Key: BR, Bank's Ridge; HPP, Horse Point Plain, PBP, Prosperous Bay Plain; UPB, Upper Prosperous Bay.

land. Typically more than half the area is unvegetated and creeper Carpobrotus edulis, Atriplex semibaccata and Suaedia helenae are the dominant plant species. Although $C$. edulis is the most important single plant, dead material comprises more than half the area covered by this species. This forms an extensive ash-like layer around the growing plants. No correlation was found between Wirebird density and percentage cover of any component species.

Mean vegetation height at Deadwood Plain in April was found not to differ significantly between paddocks within "long" and "short" groups. The combined data were therefore used to compare the group means. These differed significantly: "long" $=11.99 \mathrm{~cm}$, S.D. $=5.26$; "short" $=3.62 \mathrm{~cm}$, s.D. $=1.56$; $F(1,248)=289.3, P<0.001$. As the mean daily Wirebird count within each group did not differ significantly between days, the data were combined to compare group mean counts, which differed significantly: "long" $=12$ birds, s.D. = 3.6; "short" $=52$ birds, S.D. $=12.1 ; F(1,14)=108.2, P<0.001$. The equivalent group totals from the February census, when the grass was uniformly short, were $4^{1}$ and 35 birds respectively. The total for the "short" group did not differ from those found there after the rains $(t=1.34,8 \mathrm{df})$ but the "long" group total was significantly higher than in April $(t=7.71,8 d f, P<0.001)$. This suggests a movement away from areas of ungrazed grass after the resurgence of growth stimulated by the rains. Vegetation was significantly taller at upland sites than in intermediate pastures: $F(1,10)=8.82, P<0.05$. 
Food abundance

Beetles Coleoptera and caterpillars Lepidoptera were the most frequently observed prey. Prey identification in the field was difficult, particularly as most smaller items were swallowed before the birds raised their heads from the grass. Consequently the results are likely to be biased towards larger organisms (Figure 4). However, dissection of the gizzard (the stomach was missing) from a dead bird found on Longwood Golf Course supported the observational data. The gizzard contained eight beetles, three caterpillars and three ants. Most prey items are no more than $10 \mathrm{~mm}$ in length but birds were seen to take a $40 \mathrm{~mm}$ grasshopper and earthworms up to $120 \mathrm{~mm}$. In addition to those species listed, Wirebirds were seen to pick up a millipede Diplopoda and a carabid beetle Calosoma sp. and then drop them. As both these species secrete strong-smelling substances it is possible that they are distasteful.

Invertebrate abundance showed no significant correlation with monthly total rainfall. Temperature data were only available for one census area, Bottom Woods; invertebrate catch was not correlated with temperature at the site.

Monthly catches of invertebrates showed significant concordance between sites $\left(w=0.28, X^{2}=24.8, P<0.001,11 d f\right)$. Figure 5 shows changes in relative abundance of invertebrates at monthly-sampled sites. In 1989 there were peaks from April to June, following the onset of the rains, and early in the dry season (November-December). The latter coincides with the breeding peak of the Wirebird. It is not known if this pattern is typical of all years, however.

Bird density was regressed on the indices for all species combined and for beetles alone from the seven regularly sampled sites (Fig. 6). This produced significant positive correlations in both cases (all species: $r=0.86, P<0.05,5 d f$;

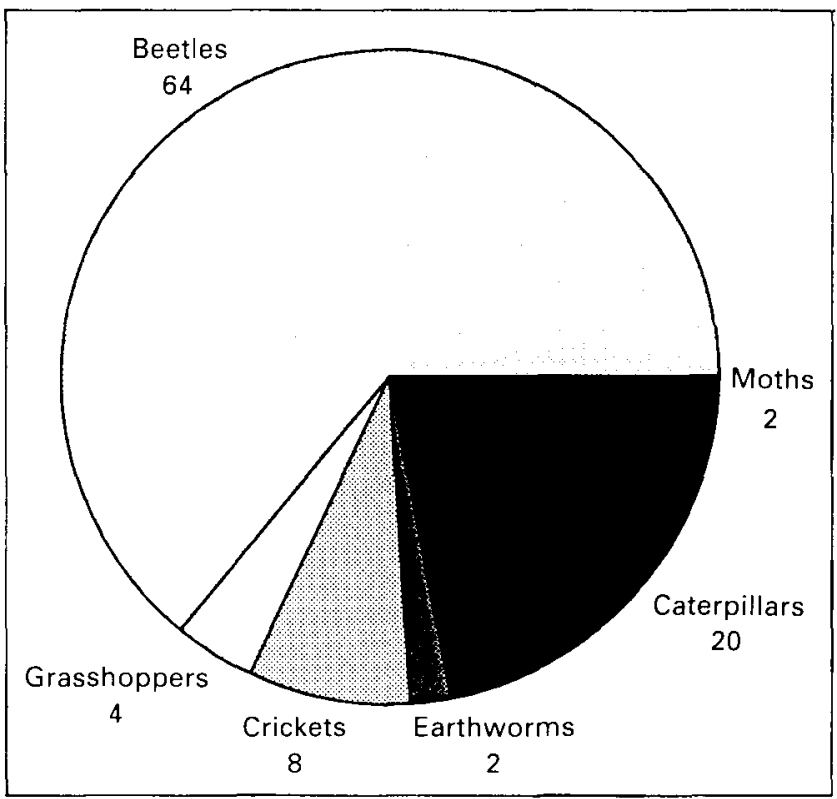

Figure 4. Percentage composition of Wirebird prey from field observations. 


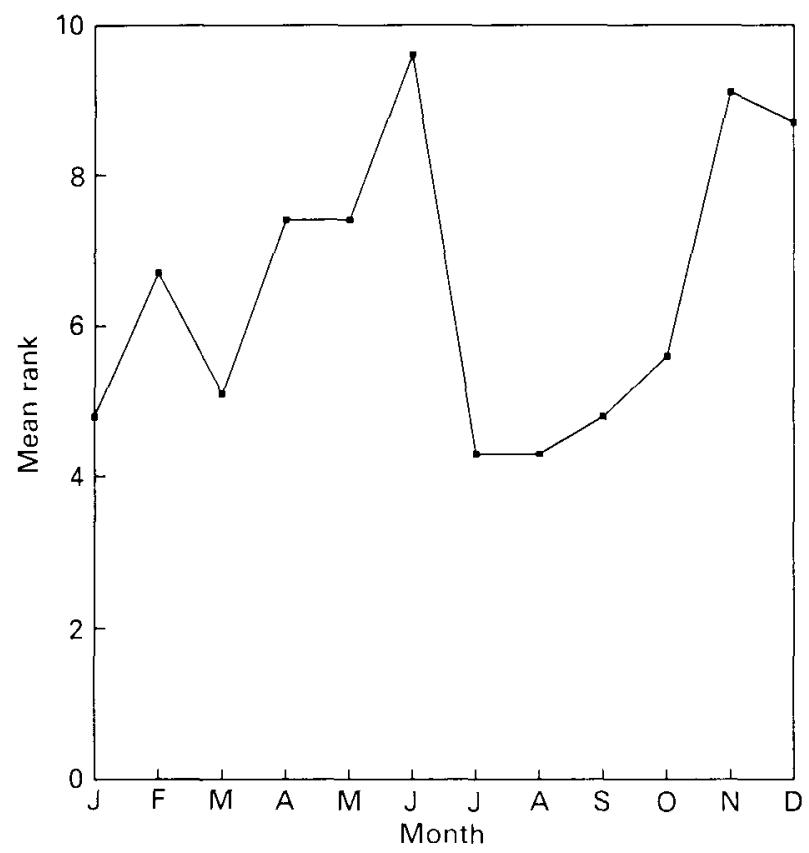

Figure 5. Seasonal variation in invertebrate abundance on St Helena based on the mean ranks of monthly catches from eight trap sites that showed statistically significant concordance.

beetles: $r=0.99, P<0.001,5 d f$ ), indicating that Wirebird distribution corresponds well with prey abundance.

\section{Discussion}

The counts made during this study indicate that the current Wirebird population is considerably larger than the most recent previous estimate (Alexander 1985). It is only possible to speculate about recent trends in numbers, however. It is likely that the population has declined since last century because of habitat loss to flax, forestry and housing, but it is not known if any significant changes have occurred during the last 50 years. Enquiries amongst the older members of the island's population produced conflicting views. Approximately half of those asked thought that the Wirebird population had declined significantly during their lifetime, whereas the others thought the species was now commoner than ever. Such observations suggest that there may have been some change in distribution but the information received was generally too vague to allow reliable conclusions to be drawn. Loveridge (1974) reported a decline in numbers around upper Deadwood Plain and Flagstaff Hill in the early 1960s, which he attributed to loss of cover as scrub was cleared to improve and extend grazing. The population appears to have recovered, however, as the numbers of breeding birds found in the Flagstaff area were similar to those recorded by Loveridge in 1957 (Loveridge 1974). This study provides a baseline estimate of the size of the Wirebird population but comparative census work will be required in the future to determine whether the population is stable. 

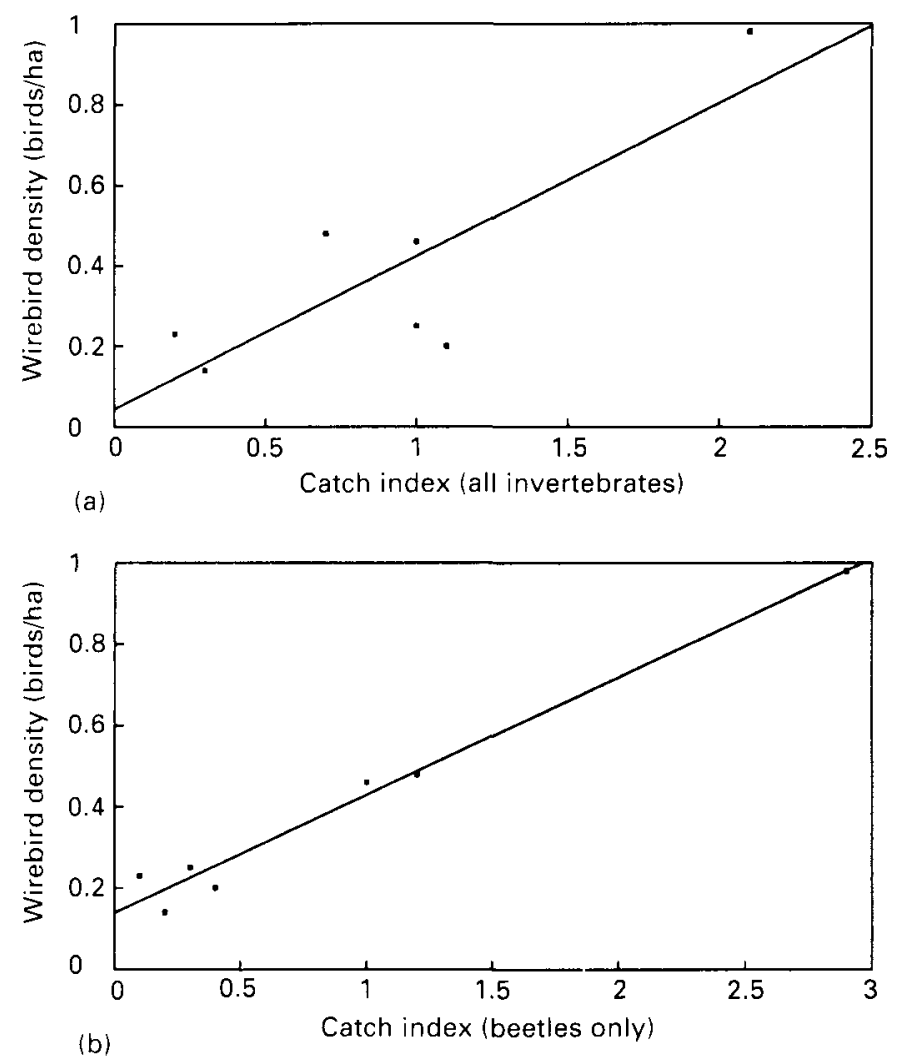

Figure 6. Relationship between mean Wirebird density and indices of abundance for (a) all invertebrates, and (b) beetles at seven trap sites.

The Wirebird suffers no direct human persecution. It is fully protected by law and is regarded with considerable affection by the islanders. However, any species with a total population of only around 500 individuals must be vulnerable to any major change of land-use within its habitat. The future of the Wirebird on St Helena is therefore inextricably linked with that of the pastures as these areas hold approximately $80 \%$ of all Wirebirds. It is therefore essential that the pastures, especially those below $600 \mathrm{~m}$, are maintained as grazing land and are managed in a manner sensitive to the needs of the Wirebird.

Possible conservation measures and assessment of the impact of proposed agricultural, forestry and amenity developments are discussed below.

\section{Agriculture}

It is unlikely that there will be any large-scale loss of pastureland to other landuse in the foreseeable future. The present pastures are a valuable resource for meat production on an island which has to import most of its foodstuffs and, as current agricultural policy is directed towards increased self-sufficiency, pastureland is likely to be protected from development. There is, however, a desire to increase the area of land under cultivation and this could lead to the 
conversion of some pastureland. Any expansion of arable land would require the use of irrigation and would therefore be dependent on major improvements to the current water supply which is inadequate, in most areas, to meet such needs.

It is, however, proposed to use effluent from a new sewage treatment plant currently under construction to provide irrigation for the Bottom Woods pasture. This would allow some 25 ha to be used for arable production. During this study Bottom Woods held, on average, 44 Wirebirds, a significant population. The mean Wirebird density (0.98/ha) was the highest of any census area, indicating that the habitat is currently of very high quality. Any environmental modification is, therefore, likely to be detrimental to the Wirebird population.

Observations at other cultivated sites, however, suggest that it is unlikely that Bottom Woods would be totally abandoned by Wirebirds after development. Less than $50 \%$ of the total pasture area would be taken into cultivation, of which only some $40 \%$ would be in production at any one time. This regime should allow ample opportunity for Wirebirds to forage. The effects of cultivation on the abundance of prey species is unpredictable but would seem unlikely to be beneficial. It is also likely that increased disturbance associated with crop husbandry would reduce the breeding success of Wirebirds attempting to nest within the developed area.

If the development goes ahead, it would be advisable to monitor its effect on habitat quality and usage of the site by Wirebirds as it might be possible to ameliorate any deleterious consequences by habitat management in adjacent areas.

There is also a possibility of some future expansion of existing arable land at Broad Bottom and Woody Ridge. However, economic circumstances may change. It is therefore important that the dependence on the pasturelands of the greater part of the Wirebird population is taken into account in the formulation of development policy. Around 25\% of all Wirebirds inhabit Deadwood Plain, and statutory protection of this most important breeding area would make a substantial contribution towards ensuring the survival of the species. This would require the drawing-up of a formal management policy taking into account the needs of the Wirebird and a long-term commitment to the area being used exclusively for grazing.

A management policy would cover such aspects as stocking density, grazing rotation, pasture improvement (including the use of fertilizers and the use of pesticides). Stocking density and rotation period may be of considerable importance during the peak breeding months because of the risk of nests being trampled. Any use of strip-grazing during the dry season is likely to cause a high rate of nest failure. However, given the poor growth of grass during this period it is highly unlikely that such a grazing regime would be feasible in the absence of irrigation.

The St Helena National Development Plan (ODA 1989) identifies pasture improvement by establishment of alternative grass species and legumes as an important component of agricultural development on the island. It has been shown that Wirebirds prefer short grass and any improvements that produced a substantial increase in vegetation height over large areas at major Wirebird sites might be detrimental to the birds by reducing both feeding efficiency and chick 
survival. Other waders breeding in grassland and cereals have been shown to be sensitive to changes in vegetation height: for example, Lapwings Vanellus vanellus tend not to nest in sites with a crop height greater than $9 \mathrm{~cm}$ if growth is dense (Cramp and Simmons 1983). The survival of Lapwing chicks has also been shown to decline with increasing vegetation height in the vicinity of the nest (Galbraith 1988). Again it is improbable that such conditions would prevail, even in improved pastures, during the dry season on St Helena.

Inorganic fertilizers are not extensively used on St Helena at present, though they have been applied to some areas of Deadwood Plain. It would be wise to exercise caution before substantially increasing the application of nitrogenous compounds at important Wirebird sites, not only because of potential effects on plant growth but also because evidence is beginning to emerge that regular treatment may reduce the numbers of soil invertebrates (Edwards 1984), which form part of the diet of the Wirebird. As so little is currently known about the effects of pasture management practices on Wirebirds it would be highly desirable to monitor the reaction of the birds to pasture improvement trials.

The limited use of pesticides on St Helena is unlikely to be a threat to the Wirebird and its prey as these are only applied to vegetable crops and fruit trees. However, as Wirebirds do forage amongst crops in a few areas, particularly at Broad Bottom, any pesticides used should be of low avian toxicity and environmental persistence to avoid the risks of poisoning and reduced fertility that have occurred in other bird species worldwide as a result of the consumption of contaminated prey.

\section{Forestry}

Wirebirds avoid dense woodland, so the afforestation of current Wirebird habitat would exclude the birds. Most expansion of forestry on St Helena is likely to take place on the fringes of the Crown Wastes to assist soil conservation. It will be constrained by rainfall and soil conditions and most of the currently barren areas inhabited by Wirebirds are classified as unsuitable for forestry, though Sane Valley, Netley Gut and Sheep Pound Gut are possible forestry sites (Brown 1981). Any such developments at these three sites would result in significant loss of Wirebird habitat.

\section{Construction}

Wirebird habitat appears unlikely to be significantly threatened by housing development in the future as environmental conservation is now given high priority in planning by the St Helena government. Pastureland sites are too valuable to the island's economy to be developed and it is improbable that any residential development in the Crown Wastes would be contemplated. There is a shortage of housing throughout the island but it is now government policy to concentrate new construction in the Half-Tree Hollow area. As a result it is certain that the little remaining Wirebird habitat along the north-west coast of the island, between Lemon Valley and Jamestown, will suffer further attrition, but as less than 20 birds now inhabit the area the effect on the population as a whole would not be great. 
Studies of the feasibility of constructing an airfield on St Helena are currently under way. It is proposed to site this on Prosperous Bay Plain where a tarmac runway $1 \mathrm{~km}$ long would be built on Wirebird breeding habitat. The long-term impact of this might not be particularly serious, however, as the Wirebird density at this site is low. The birds in other parts of the island have also shown themselves to be adaptable to human disturbance. Given the propensity of its close relative, Kittlitz's Sand-plover, for nesting on airfields and similar sites in Africa it would seem reasonable to expect that, after the disturbance of the construction phase, Wirebirds would return to nest within the airfield perimeter. Subsequent disturbance would not be high as only two flights per week are projected. It is, however, by no means definite that the airfield will be built, at least in the near future, as the commercial viability of the project is uncertain.

It is probable that a wind-powered generator will be sited at Deadwood Plain in the near future. Although there will undoubtedly be disturbance during construction, studies of similar machines in Holland and the United Kingdom have shown that they are unlikely to endanger or disturb birds to a significant degree (Winkelman 1985; C. J. Mead verbally 1991). This would apply particularly to species like the Wirebird which is so predominantly terrestrial.

\section{Predation}

Most potential predators (dogs, cats and rodents) have existed on St Helena for several hundred years, and records suggest that all have been more numerous in the past. Despite this the Wirebird population is still substantial, and it may be that the species had adapted to the presence of these long-established threats, though complacency should be avoided.

The current rodent control programme should be continued at least at its present level but, despite the attractiveness of the idea, no predatory animal should be introduced to St Helena to control rodents. On other islands throughout the world such introductions have had disastrous consequences for the native fauna. Any new vertebrate predator would be a threat to Wirebirds, particularly to chicks.

An increase in cat-trapping in the Longwood area would be of some benefit to the Wirebird, as would stricter legislation on the control of dogs throughout the island.

The Common Myna is the most recently introduced potential predator on St Helena. Their numbers have increased rapidly and there may be a need for them to be controlled. However, more information about their population dynamics and their impact on the Wirebird population through predation and competition is needed.

Some islanders occasionally take Wirebird eggs and chicks with the intention of rearing them as pets, although this is illegal. Rearing is usually unsuccessful but attempts are rare and unlikely to have any significant impact on the population. Raising public awareness of the uniqueness and rarity of the Wirebird might help to eradicate such actions. 


\section{Conclusions and recommendations}

The Wirebird does not appear to be directly threatened at present but, with a population of only some 500 individuals, the species must be considered vulnerable. The current population trend is, however, quite unknown in the absence of reliable earlier population estimates. There may be substantial changes in agricultural practices on St Helena in the future, the impact of which cannot be fully predicted on the basis of the limited data gathered during this study. More information is needed on effects of pasture management on Wirebirds and on the causes of nest failure and pre-fledgling mortality. The role of the Common Myna as a competitor and probable predator of the Wirebird also needs to be clarified.

The following points are suggested as the basis for a conservation strategy for the Wirebird:

(1) designation of Deadwood Plain/Flagstaff as a special protected area within which land use is restricted to grazing and management practices compatible with the requirements of the Wirebird;

(2) maintenance of the other areas currently under pasture as grazing land, especially those at Man and Horse, Botleys Lay, Broad Bottom, Sane Valley, Middle Point and as large an area as possible at Bottom Woods;

(3) livestock densities to be held at, or preferably below, present levels at important sites during the main Wirebird breeding season (October-March);

(4) restrictions on the use of pesticides and herbicides in Wirebird breeding areas (where the use of the above is essential, only non-persistent compounds of low avian toxicity should be applied);

(5) intensification of control measures against feral cats in rural areas, particularly around Longwood;

(6) maintenance of the current rodent control programme;

(7) maintenance of stringent measures against the importation of avian diseases;

(8) establishment of long-term monitoring of Wirebird numbers (to be carried out by experienced or appropriately trained personnel at intervals of not more than five years);

(9) further research into factors affecting Wirebird breeding success and into its utilization of cultivated land;

(10) investigation of the diet and population dynamics of the Common Myna on St Helena with a view to establishing its significance as a competitor and predator of the Wirebird;

(11) increasing the awareness of St Helena's unique natural heritage amongst islanders, particularly children, through the schools (especially at Junior and Middle levels) and the local media (to be supported by the production of introductory literature of a style and price appropriate to island readership). 


\section{Acknowledgements}

Fieldwork on St Helena was funded by the Worldwide Fund for Nature (U.K.), the International Council for Bird Preservation (U.K.) and the Peter Scott Trust for Education and Research in Conservation. Additional financial support was received from the Iris Darnton Foundation, the Peter Nathan Charitable Trust, and the International Trust for Nature Conservation. The project was administered by the British Trust for Ornithology and supervised by Dr J. J. D. Greenwood. I am most grateful to them all.

I am indebted to $\mathrm{Mr} \mathrm{A}$. Dunthorn who assisted me in the final stages of fieldwork. I thank their Excellencies Governors F. E. Baker and R. F. Stimson for permission to carry out fieldwork on St Helena, and Mr V. Hart, Agriculture and Forestry Officer, for the generous assistance given by himself and many of his staff. Mr I. K. Mathieson provided much useful climatic data and Mr G. Benjamin gave invaluable assistance in identifying plant specimens.

I am extremely grateful to $\mathrm{Mr}$ and Mrs N. Thorpe for providing accommodation at very short notice and to numerous friends on St Helena who assisted me with transport.

\section{References}

Alexander, C. (1985) The St Helena Wirebird: its status and distribution. Unpublished.

Ashmole, N. P. (1963) The extinct avifauna of St Helena island. Ibis 103b: 390-408.

Atkinson, I. A. E. (1985) The spread of commensal species of Rattus to oceanic islands and their effect on island avifaunas. Pp.35-81 in P. J. Moors, ed. Conservation of island birds. Cambridge, U.K.: International Council for Bird Preservation (Techn. Publ. 3).

Baker, E. (1868) The birds of St Helena. Zoologist (2)3: 1472-1476.

Baker, I. (1970) Geological history of Saint Helena in relation to its floral and faunal colonization. Pp.25-35 in: La faune terrestre de l'île Sainte-Hélène. Ann. Mus. Roy. Afrique Centrale Ser. 8, Sci. Zool. 181.

Baker, I., Gale, N. H. and Simons, J. (1967). Geochronology of the St Helena volcanoes. Nature 215: 1451-1456.

Basilewsky, P. (1970) Vertébrés. Pp.77-130 in: La faune terrestre de l'île de Sainte-Hélène. Ann. Mus. Roy. Afrique Centrale Ser. 8, Sci. Zool. 181.

Beatson, A. (1816) Tracts relative to the Island of St Helena. Jamestown, St Helena.

Beintema, A. J. (1982) Meadow birds in The Netherlands. Rijksinstituut voor NatuurbeheerRapport 1981: 86-93.

Benson, C. W. (1950) A contribution to the ornithology of St Helena, and other notes from a sea voyage. Ibis 92: 75-83.

Bock, W. J. (1958) A generic review of the plovers (Charadrinae, Aves). Bull. Mus. Comp. Zool. 118: 27-97.

Brown, L. C. (1981) The land resources and agro-forestal development of St Helena (three volumes). Tolworth: Ministry of Overseas Development Land Resource Study 32.

Brown, L. C. (1982) The flora and fauna of St Helena. Tolworth: Ministry of Overseas Development Project Report 59.

Clarke, D. (1990) Invertebrates - The "Project Hercules" expedition. Pp.15-16 in P. Pearce-Kelly and Q. C. B. Cronk, eds. St Helena, natural treasury. Proceedings of a symposium held at the Zoological Society of London, 9th September 1988. London: Zoological Society of London.

Collar, N. J. and Stuart, S. N. (1985) Threatened birds of Africa and related islands. Cambridge, U.K.: International Council for Bird Preservation. 
Cramp, S. and Simmons, K. E. L., eds. (1983) The birds of the western Palearctic, 3. Oxford: Oxford University Press.

Cronk, Q. C. B. (1983) The decline of the redwood Trochetiopsis erythroxylon on St. Helena. Biol. Conserv. 26: 163-174.

Cronk, Q. C. B. (1986a) The decline of the St Helena ebony Trochetiopsis melanoxylon. Biol. Conserv. 35: 159-172.

Cronk, Q. C. B. (1986b) The decline of the St Helena Gumwood Commidendrum robustum. Biol. Conserv. 35: 173-186.

Cronk, Q. C. B. (1987) The history of endemic flora of St Helena: a relictual series. New Phytol. 105: 509-520.

Cronk, Q. C. B. (1989) The past and present vegetation of St Helena. J. Biogeog. 16:47-64.

Daly, R. A. (1927) The geology of St Helena Island. Proc. Amer. Acad. Arts Sci. 62: 31-92.

Edwards, C. A. (1984) Changes in agricultural practice and their impact on soil organisms. Pp. 56-65 in D. Jenkins, ed. Agriculture and the environment. Cambridge, U.K.: Institute of Terrestrial Ecology.

Flemming, S. P., Chiasson, R. D., Smith, P. C., Austin-Smith, P. J. and Bancroft, R. P. (1988) Piping Plover status in Nova Scotia related to its reproductive and behavioral responses to human disturbance. J. Field Orn. 59: 321-330.

Galbraith, H. (1988) Effects of agriculture on the breeding ecology of Lapwings Vanellus vanellus. J. Appl. Ecol. 25: 487-503.

Gosse, P. (1938) St Helena, 1502-1938. London: Cassell and Company.

Harting, J. E. (1873) On rare or little known Limicolae. Ibis (3)3: 260-269.

den Hartog, J. C. (1984) A note on the avifauna of St Helena, South Atlantic Ocean. Bull. Brit. Orn. Club 104: 91-95.

Haydock, E. L. (1954) A survey of the birds of St Helena island. Ostrich 25: 62-75.

Huckle, C. H. (1924) Birds of Ascension and St Helena. Ibis 11(6): 818-821.

Layard, E. L. (1867) Letter. Ibis (2)3: 248-252.

Lessells, C. M. (1984) The mating system of Kentish Plovers Charadrius alexandrinus. Ibis 126: $474-483$.

Loveridge, A. (1974) Notes on the vertebrates of St Helena Island. Unpublished.

Markham, C. R., ed. (1911) Early Spanish voyages to the Straits of Magellan. London: Hakluyt Society (Series II, No. 38).

Mathieson, I. K. (1990) The agricultural climate of St Helena (with reference to Ascension). London: Overseas Development Administration, and St Helena: Department of Agriculture and Forestry.

Maxson, S. and Oring, L. (1978) Mice as a source of egg loss among ground-nesting birds. Auk 95: 582-584.

McCulloch, M. N. (in prep.) The status and ecology of the St Helena Wirebird. Thetford, Norfolk: British Trust for Ornithology (research report).

Mellis, J. C. (1871) Notes on the birds of the island of St Helena. Ibis (3)6: 97-107.

Moreau, R. E. (1931) Some birds on a voyage. Ibis 13(1): 778-781.

Morris, D. (1884) Report upon the present conditions and prospects of the agricultural resources of the island of St Helena. London: Miscellaneous Colonial Report No. 38.

Nunn, P. D. (1990) Geomorphology. Pp.3-4 in P. Pearce-Kelly and Q. C. B. Cronk, eds. St Helena, natural treasury. Proceedings of a symposium held at the Zoological Society of London, $9^{\text {th }}$ September 1988. London: Zoological Society of London.

O'Connor, R. J. and Shrubb, M. (1986) Farming and birds. Cambridge, U.K.: Cambridge University Press.

Olson, S. L. (1975) The palaeornithology of St Helena Island, South Atlantic Ocean. Smithsonian Contrib. Paleobiol. No. 23.

Overseas Development Administration (ODA) (1989) St Helena National Development Plan. London: Overseas Development Administration. 
Pitman, C. R. S. (1965) The eggs and nesting habits of the St Helena Sand-Plover or Wirebird Charadrius pecuarius sanctae-helenae (Harting). Bull. Brit. Orn. Club 85: 121-129. Sclater, W. L. (1924) Systema avium Aethiopicarum. London: British Ornithologists' Union. Simmons, G. F. (1927) Sinbads of science. Natn. Geogr. Mag. 52: 1-75.

Sokal, R. R. and Rohlf, F. J. (1981) Biometry. Second edition. San Francisco: Freeman and Company.

Temple, R. C., ed. (1914) The travels of Peter Mundy in Europe and Asia, 1608-1667, 2. London: Hakluyt Society (Series II, No. 35).

Temple, R. C., ed. (1919) The travels of Peter Mundy in Europe and Asia, 1608-1667, 3. London: Hakluyt Society (Series II, No. 46).

Temple, R. C. and Anstey, L. M., eds. (1936) The travels of Peter Mundy in Europe and Asia, $1608-1667,5$. London: Hakluyt Society (Series II, No. 78).

Winkelman, J. E. (1985) Impact of medium-sized wind turbines on birds: a survey on flight behaviour, victims and disturbance, Neth. J. Agric. Sci. 33: 75-78.

M. NEIL MCCULLOCH

British Trust for Ornithology, The Nunnery, Thetford, Norfolk IP24 $2 P U, U . K$. 